\title{
Ontogeny of osmoregulation, physiological plasticity and larval export strategy in the grapsid crab Chasmagnathus granulata (Crustacea, Decapoda)
}

\author{
G. Charmantier ${ }^{1, *}$, L. Giménez ${ }^{2}$, M. Charmantier-Daures ${ }^{1}$, K. Anger $^{3}$ \\ ${ }^{1}$ Laboratoire d'Ecophysiologie des Invertébrés, EA 3009 Adaptation Ecophysiologique au cours de l'Ontogenèse, \\ Université Montpellier II, Place Eugène Bataillon, 34095 Montpellier cedex 05, France \\ ${ }^{2}$ Sección Oceanografía, Facultad de Ciencias, Universidad de la República, Iguá 4225, 11400 Montevideo, Uruguay \\ ${ }^{3}$ Biologische Anstalt Helgoland, Stiftung Alfred-Wegener-Institut für Polar- und Meeresforschung, 27498 Helgoland, Germany
}

\begin{abstract}
The grapsid crab Chasmagnathus granulata populates brackish-water lagoons and other estuarine environments. In its reproduction, this species follows a strategy of larval export, i.e. its larvae live under different salinity conditions from the juveniles and adults. In the present experimental investigation, ontogenetic changes in the capability for osmoregulation were studied in all 4 zoeal stages, the megalopa, the juvenile crab instars I, II and IV, and adults (all reared in seawater, $32 \%$ ). Moreover, we studied effects of embryonic and larval acclimation on osmoregulation. The zoea I larvae were slight hyper-regulators at low salinities (10 to 17\%o) and hyper-osmoconformers at higher salinities. Stages II to IV zoeae were generally hyper-osmoconformers. At metamorphosis to the megalopa, the type of osmoregulation changed to hyper-hypo-regulation. The osmoregulatory capacities under both hypo- and hypersaline conditions increased strongly in the crab I and throughout later juvenile development. These patterns in osmoregulation match the ontogenetic changes that typically occur in the ecology of $C$. granulata: the zoea I hatches in brackish estuarine waters, where the juveniles and adults live, before it is exported to coastal marine zones. This initial larval stage is euryhaline and capable of hyper-osmoregulation at low salinities. The same capabilities were observed in the megalopa, which re-invades the brackish adult environment. This stage is known to settle in semiterrestrial habitats near the adult burrows, where both brackish and hypersaline conditions are likely to occur; this coincides with the first ontogenetic appearance of the hyper-hypoosmoregulation pattern. The zoeal stages II, III and IV, in contrast, develop in the adjacent sea, where the salinity is higher and more stable. Correspondingly, these intermediate larval stages were found to be stenohaline osmoconformers. Preceding exposure of the eggs and larvae to a reduced salinity $(20 \%$ ) enhanced the hyper-osmoregulatory capacity at low salinities (5 to $10 \%$ ) in all zoeal stages. This indicates an effect of non-genetic acclimation and, hence, phenotypic plasticity. This trait should have an adaptive value, as it increases the chance of larval survival, at least in the initial larval stage, which is in the field exposed to highly variable, mostly reduced salinities.
\end{abstract}

KEY WORDS: Osmoregulation · Ontogeny · Metamorphosis · Phenotypic plasticity · Export strategy · Crustacea $\cdot$ Brachyura $\cdot$ Chasmagnathus

- Resale or republication not permitted without written consent of the publisher

\section{INTRODUCTION}

In a recent review on the ontogeny of osmoregulation in crustaceans, Charmantier (1998) underlined that

*E-mail: charmantier@univ-montp2.fr adaptations to particular salinity regimens are necessary in each stage of development as a requirement for the establishment of a species in a given environment. This conclusion was drawn from a series of studies that have been published mostly in the past 2 decades (listed in the above-mentioned review). The 
necessity of adaptation to salinity and its variations is particularly apparent in estuarine waters. Crustaceans whose adults live in these habitats may exhibit 2 alternative principal strategies of dispersal and recruitment (review in Strathmann 1982): some species retain their larvae within the system where the adults are found, whereas others show behavioral mechanisms that lead to an export of their larvae to coastal shelf or oceanic waters; re-immigration and recruitment to the adult population occurs, in these species, in later lifehistory stages. In the retention strategy, all developmental stages are exposed to brackish or variable salinity conditions, while the export strategy allows for larval development at higher and more stable seawater salinity.

In the past few years, different research groups have embarked in studies of the relationships between salinity tolerance and the ontogeny of osmoregulation in crustaceans, attempting to show that tolerance of low, high or variable salinities observed in larval or other early life-cycle stages is due to an early appearance of osmoregulatiory abilities. This relationship has been shown in the isopod Sphaeroma serratum (Charmantier \& Charmantier-Daures 1994), in the amphipods Gammarus duebeni (Morritt \& Spicer 1995) and Orchestia gammarellus (Morritt \& Spicer 1996, 1998, 1999), and in the decapods Armases miersii (Charmantier et al. 1998), Sesarma curacaoense (Anger \& Charmantier 2000), Palaemonetes argentinus (Charmantier \& Anger 1999) and Astacus leptodactylus (Susanto \& Charmantier 2000). These species all exhibit a retention strategy, i.e. they live and develop exclusively within the adult environment. Their early postembryonic stages consistently display a strong ability to osmoregulate, particularly to hyper-regulate at low salinity or, in some species, in freshwater.

The objective of the present study was to investigate the ontogeny of osmoregulation in a species that uses an export strategy, namely the grapsid crab Chasmagnathus granulata. This euryhaline semiterrestrial species is distributed in estuaries and lagoons along the Atlantic coast of South America, from Rio de Janeiro, Brazil, to northern Patagonia, Argentina (Boschi 1964). Its ecology, burrowing activity and reproduction have been studied extensively in southern Brazil (D'Incao et al. 1992) and, in particular, in Mar Chiquita lagoon, Argentina (Spivak et al. 1994, Iribarne et al. 1997, Luppi et al. 1997, 2001, Bortolus \& Iribarne 1999, Botto \& Iribarne 1999, 2000, Luppi 1999). This coastal lagoon comprises salt marshes where the physical conditions are highly variable (Anger et al. 1994). It is inhabited by several species of intertidal crabs, with C. granulata as a dominant species. Its larval development normally comprises 4 zoeal stages (Boschi et al. 1967), with an additional fifth stage occurring under unfavorable conditions (Pestana \& Orstrensky 1995, Giménez 2000), followed by a megalopa and the first juvenile crab stage.

Chasmagnathus granulata shows an export strategy during its larval development (Anger et al. 1994): soon after hatching, the zoea I larvae leave the estuary with outflowing tidal currents, and the subsequent planktonic development occurs in the open sea, where salinity is on average higher and more constant. The megalopae re-invade estuaries and lagoons, where they settle and metamorphose to the first juvenile stage (Luppi 1999, Luppi et al. 2001). Juvenile growth, reproduction and embryonic development occur in estuarine environments. Adults of this crab are strong hyper-hypo-osmoregulators (Mañe-Garzón et al. 1974, Luquet et al. 1992, Nery \& Santos 1993), which is a typical trait of intertidal and estuarine grapsid crabs (reviewed in Mantel \& Farmer 1983).

In Chasmagnathus granulata, variability in salinity experienced during egg development may affect embryonic and early larval survival (Bas \& Spivak 2000, Giménez \& Anger 2001). When embryogenesis occurs at $20 \%$, the survival of zoea I larvae at low salinities (5 to $10 \%$ ) was observed to be higher than in larvae hatching from eggs that had been incubated in full-strength seawater (Giménez 2000). This effect indicates an acclimation process that may buffer the consequences of variability in the salinity conditions and thus should enhance early larval survival in the field.

In an experimental laboratory study, we measured ontogenetic changes in the osmoregulatory abilities of Chasmagnathus granulata; and we investigated the effects of acclimation to a reduced salinity during embryonic and larval development on the ability of subsequent larval stages to tolerate hypo-osmotic stress and to osmoregulate. These experimental data are analyzed in relation to the reproductive strategy of this species, i.e. initial larval export from and later re-immigration to estuarine waters.

\section{MATERIALS AND METHODS}

Collection and maintenance of crabs. Juvenile and adult Chasmagnathus granulata were collected in Mar Chiquita lagoon, Argentina $\left(37^{\circ} 33^{\prime} \mathrm{S}, 57^{\circ} 20^{\prime} \mathrm{W}\right)$, and transported to the Helgoland Marine Station, Germany. They were maintained in flow-through aquaria with constant temperature $\left(21 \pm 0.5^{\circ} \mathrm{C}\right)$ and salinity (32\%), and a $12 \mathrm{~h}$ light:12 h dark cycle. Frozen shrimps Crangon crangon and isopods Idotea spp. were given daily as food.

Rearing of larvae. In the study of the ontogeny of osmoregulation, ovigerous females and larvae were 
exclusively exposed to seawater (32\%). The larvae were mass reared in $10 \mathrm{l}$ bottles; water and food (freshly hatched Artemia sp. nauplii) were changed daily, and the larvae were checked microscopically for deaths or molts. Temperature and light conditions were the same as for adult crabs. In the study of acclimation effects on larval osmoregulation and salinity tolerance, eggs and larvae were constantly maintained at a reduced salinity $(20 \%)$; otherwise, the rearing conditions were the same.

Upon molting, different instars were sorted and reared in separate bottles, so that the cultures were maintained homogeneous (i.e. in each bottle, the larval stage and age within an instar were identical). The average development durations in successive instars were as follows: $5 \mathrm{~d}$ in the zoeal stages I to III, 5 to $6 \mathrm{~d}$ in the zoea IV, $12 \mathrm{~d}$ in the megalopa and $7 \mathrm{~d}$ in the crab I. Molt stages within each instar (Drach 1939) were estimated according to the time elapsed since hatching (zoea I) or since the last preceding ecdysis (later stages). Hemolymph samples were exclusively collected from individuals in the middle of an instar, i.e. in the intermolt stage, $\mathrm{C}$, of Drach's classification system. The validity of this staging method was occasionally confirmed through microscopical observations (Anger 1983). Stage C adult crabs were selected after checking the exopodite of the maxillipede (Drach \& Tchernigovtzeff 1967).

Preparation of media. Experimental media were prepared from natural North Sea water by dilution with desalinated freshwater or adding Tropic Marin ${ }^{\circledR}$ salt (Wartenberg, Germany). All experiments were conducted at $21^{\circ} \mathrm{C}$. Salinities were expressed as osmolality (in mOsm $\mathrm{kg}^{-1}$ ) and as salt content of the medium (in \%o); a value of $3.4 \%$ is equivalent to $100 \mathrm{mOsm} \mathrm{kg}^{-1}$ (29.41 mOsm kg $\mathrm{kg}^{-1} 1 \%{ }^{-1}$ ). The osmolality of the media was measured with a micro-osmometer Model 3MO (Advanced Instruments, Needham Heights, MA, USA) requiring $20 \mu \mathrm{l}$ sample $^{-1}$. Media with the following osmolalities and salinities were prepared, stored at $21^{\circ} \mathrm{C}$ and used for all stages: $30 \mathrm{mOsm} \mathrm{kg}{ }^{-1}(1.0 \%)$, 155 mOsm kg-1 $(5.3 \%), 300$ mOsm kg $\mathrm{kg}^{-1}(10.2 \%$ o), $500 \mathrm{mOsm} \mathrm{kg}{ }^{-1}(17.0 \%), 749 \mathrm{mOsm} \mathrm{kg}^{-1}$ (25.5\%), $947 \mathrm{mOsm} \mathrm{kg}^{-1}$ (32.2\%o, referred to as 'seawater') and $1302 \mathrm{mOsm} \mathrm{kg}^{-1}$ (44.3\%o).

Measurements of hemolymph osmolality. Zoeae, megalopae and young crabs were sampled from the cultures (32 or $20 \%$ salinity) and transferred to covered petri dishes, where they were directly exposed to the experimental media; adult crabs were placed in $250 \mathrm{ml}$ glass bowls covered with a convex glass lid. Since the hemolymph osmolality reaches a steady state relative to the ambient water osmolality within a few hours (larvae and young crabs) or in approximately $1 \mathrm{~d}$ (adults) (Charmantier 1998, Charmantier et al. 1998), we allowed for an acclimation time of 24 to $30 \mathrm{~h}$ in larvae and juveniles and of $48 \mathrm{~h}$ in adults, respectively, in each medium. In the study of the ontogeny of osmoregulation, all 7 experimental media (30 to $1302 \mathrm{mOsm} \mathrm{kg}^{-1}$ ) were tested. In the acclimation study, osmoregulation was measured only in the larval stages, not in juveniles and adults, and the zoea II and megalopa were exposed to only 2 media with reduced salinities (155 mOsm kg-1 or 5.2\%; $300 \mathrm{mOsm} \mathrm{kg}^{-1}$ or $10.2 \%$ ); otherwise the experimental techniques and protocols were identical in these 2 sets of experiments.

Larvae and young crabs (instars I, II and IV) were quickly rinsed in deionized water, superficially dried on filter paper, and then quickly immersed in mineral oil to avoid evaporation and desiccation. The remaining adherent water was aspirated through a first glass micropipette. In the next step, the hemolymph was sampled with a second micropipette inserted into the heart. In adult crabs, the hemolymph was collected through a hypodermic needle after sectioning the propodite of a posterior pereiopod previously rinsed with deionized water and dried with filter paper. The hemolymph was then immediately transferred into mineral oil. Hemolymph osmolality was measured with reference to the medium osmolality on a Kalber-Clifton nanoliter osmometer (Clifton Technical Physics, Hartford, NY, USA) requiring about $30 \mathrm{nl}$. The results were expressed either as hemolymph osmolality or as osmoregulatory capacity (OC), defined as the difference between the osmolalities of the hemolymph and of the medium.

Short-term salinity tolerance in osmoregulation experiments. No comprehensive study of the effect of salinity on survival was conducted, but at the end of each experiment (before sampling hemolymph) the larvae were microscopically checked for mortality; the criterion for death was the lack of movement after repeated probing with a delicate forceps. The number of individuals used in each treatment depended on the availability of live material in each stage and on the expected mortality. The percentage of mortality during the experimental exposure to the various test salinities is thus used here as an additional (preliminary) information on larval salinity tolerance.

Acclimation during embryogenesis: effects on salinity tolerance of the zoea I. Three groups with 4 ovigerous females each were maintained from egg laying at salinities of 15,20 and $32 \%$, respectively, until zoeae hatched (prehatching salinities). After hatching, zoea I larvae from each brood were randomly assigned to $5,15,25$ and $32 \%$ o (posthatching salinities). The larvae were maintained in vials with $80 \mathrm{ml}$ filtered water (without food) until all individuals died. In each combination of pre- and posthatching salinity, 5 groups with 10 larvae were used as replicate experiments. These 
were checked daily during water change; dead individuals were discarded. Temperature and light conditions were the same as in all other experiments.

Larval salinity tolerance was estimated using $L t_{50}$ values, i.e. the time elapsed from hatching until mortality reached $50 \%$. For each replicate, we obtained a mortality curve with the cumulative number of dead animals, $M(t)$, as a function of the time ( $t$, in days) from hatching. This relationship was adjusted with a sigmoid function:

$$
M(t)=10 /\left(1+10^{\left(L t_{50}-t\right)}\right)
$$

Statistical methods. ANOVA and Student's $t$-tests were used for multiple and pairwise statistical comparisons of mean values, respectively, after appropriate checks for normal distribution and equality of variance (Sokal \& Rohlf 1995). For statistical analysis of mortality data, the factors considered were prehatching salinity (3 levels: 15, 20 and 32\%), posthatching salinity (4 levels: 5, 15, 25 and 32\%o), and brood (4 levels). A 2-way ANOVA (with both types of salinities as fixed factors) and with brood as random factor, nested in prehatching salinity was used to test for effects on $L t_{50}$. Normality was checked with normal plots and variance heterogeneity with Cochran tests. We found that raw as well as $\log$-transformed data $(\log x+1)$ showed heterogeneous variance. However, we proceeded with the ANOVA, since our design did not allow for the use of a Welch ANOVA (Day \& Quinn 1989). In this analysis, we used the log-transformed data as these were less heterogeneous $(0.05>p>0.01)$. A check of variances allowed the identification of treatment combinations with high variances, so that we can discuss the effects of variance heterogeneity on the outcome of the analysis.

Table 1. Chasmagnathus granulata. Percentage survival at different stages of development according to the ambient salinity, following 24 to $30 \mathrm{~h}$ exposure ( $48 \mathrm{~h}$ in adults). Number of individuals at the start of the experiment: 20 to 64 (zoeae, megalopae), 10 to 12 (crabs I to IV), 7 to 8 (adults). CI to CIV: juvenile crab stages; ZI to ZIV: zoeal stages

\begin{tabular}{|lccccccc|}
\hline \multirow{2}{*}{ Stages } & \multicolumn{7}{c|}{ Salinity: Osm $\mathrm{kg}^{-1}(\%)$} \\
& 30 & 155 & 300 & 500 & 749 & 947 & 1302 \\
& $(1.0)$ & $(5.3)$ & $(10.2)$ & $(17.0)$ & $(25.5)$ & $(32.2)$ & $(44.3)$ \\
\hline ZI & 0 & 17.5 & 68.0 & 100 & 100 & 100 & 100 \\
ZII & 0 & 0 & 17.9 & 100 & 100 & 100 & 100 \\
ZIII & 0 & 0 & 0 & 100 & 100 & 100 & 100 \\
ZIV & 0 & 0 & 46.7 & 100 & 100 & 100 & 100 \\
Megalopa & 0 & 0 & 26.3 & 100 & 95.0 & 100 & 100 \\
CI & 100 & 100 & 100 & 100 & 100 & 100 & 100 \\
CII & 100 & 100 & 100 & 100 & 100 & 100 & 100 \\
CIV & 100 & 100 & 100 & 100 & 100 & 100 & 100 \\
Adults & 100 & 100 & 100 & 100 & 100 & 100 & 100 \\
& & & & & & & \\
\hline
\end{tabular}

\section{RESULTS}

\section{Short-term salinity tolerance}

The percentage survival in the different stages during 24 to $30 \mathrm{~h}$ exposure to the experimental media is given in Table 1. Survival in the juvenile and adult crabs was $100 \%$ in all tested salinities. Zoeae and megalopae survived in all media with $\geq 500 \mathrm{mOsm} \mathrm{kg}^{-1}$ (>17\%o). At $300 \mathrm{mOsm} \mathrm{kg} \mathrm{kg}^{-1}(10.2 \%$ ), zoeal survival was generally low, with complete mortality in the zoea III stage; the highest survival rate in this medium (68\%) was observed in the zoea I stage. At $155 \mathrm{mOsm} \mathrm{kg}{ }^{-1}$ (5.3\%), all larvae except for a few (18\%) zoea I died. No larva survived at the lowest salinity $\left(30 \mathrm{mOsm} \mathrm{kg}{ }^{-1}\right.$ or $1.0 \%$ ), so that no data of larval osmoregulation could be obtained from this treatment.

\section{Ontogenetic changes in osmoregulation}

The results are given as variations in hemolymph osmolality (Fig. 1) and as OC in relation to the osmolality of the medium (Fig. 2). In the adults, no difference in osmoregulation was found between males and females and their results were pooled.

The ability to osmoregulate at both low and high salinities changed according to the developmental stage. Among the zoeal stages, only a few zoea I larvae survived at a salinity as low as 155 mOsm kg-1 (5.3\%o; see Table 1); they were isosmotic with the medium (Fig. 2). The initial stage also consistently had, among

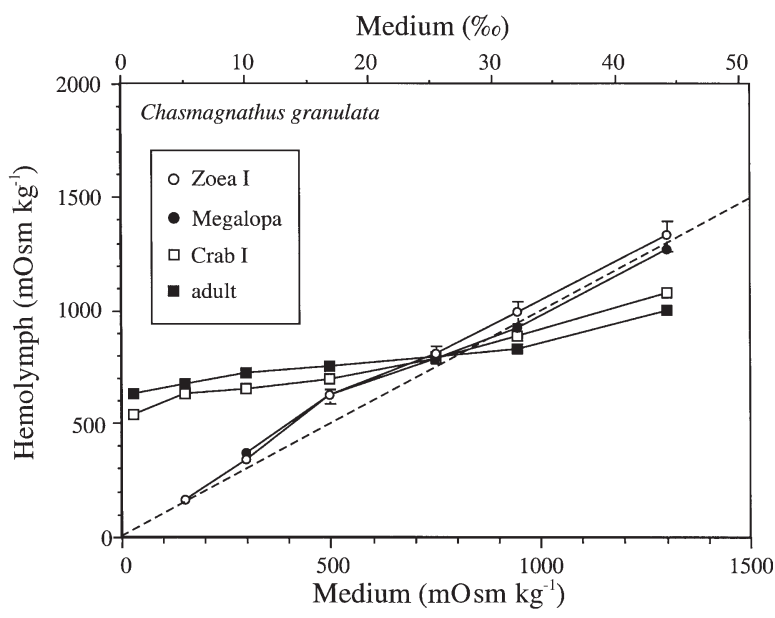

Fig. 1. Chasmagnathus granulata. Variations of the hemolymph osmolality in selected stages of postembryonic development in relation to the osmolality and salinity of the medium at $21^{\circ} \mathrm{C}_{i}$ error bars: mean $\pm \mathrm{SD}_{;} \mathrm{n}=6$ to 10 individuals; dashed line: isoconcentration. Data for all studied stages are given in Fig. 2 


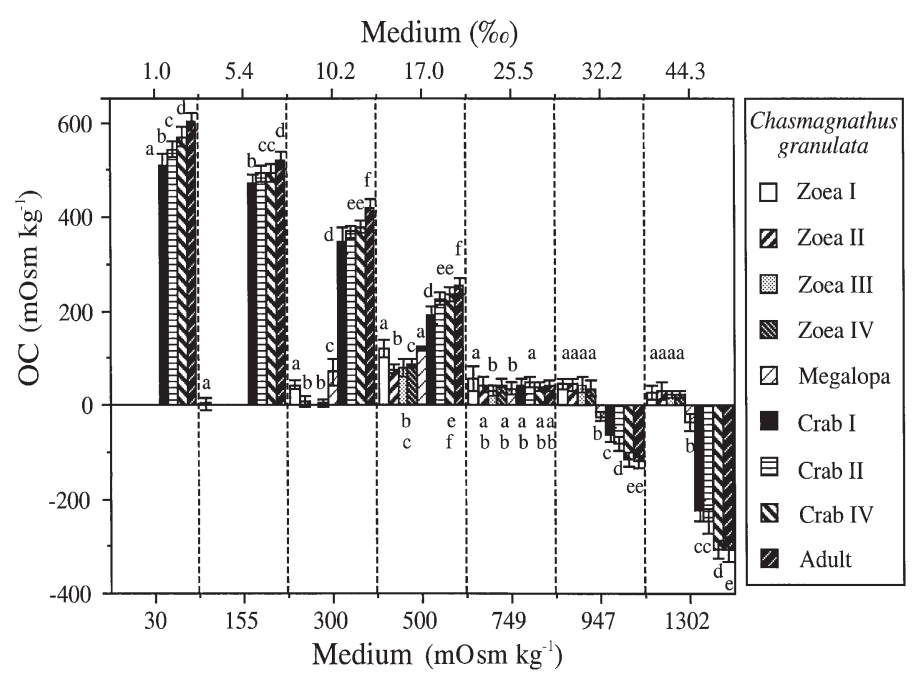

Fig. 2. Chasmagnathus granulata. Variations of the osmoregulatory capacity $(\mathrm{OC})$ in different stages of postembryonic development in relation to the osmolality and salinity of the medium at $21^{\circ} \mathrm{C}_{i}$ error bars: mean $\pm \mathrm{SD}_{;} \mathrm{n}=6$ to 10 individuals; different letters near error bars indicate significant differ ences between stages at each salinity $(p<0.05)$

the zoeae, the highest, although slight, ability to hyperregulate at 300 and $500 \mathrm{mOsm} \mathrm{kg}^{-1}$ (10.2\% and $17.0 \%$; Fig. 2). At higher salinities, the zoea I remained close to osmoconformity, as all other zoeae. All later zoeal stages osmoconformed or hyper-osmoconformed at all salinities that were tolerable for the duration of the exposure (24 to $30 \mathrm{~h}$ ). A slight hyper-osmoregulation was noticeable only in the 500 mOsm $\mathrm{kg}^{-1}$ (17.0\%) medium. Zoea V larvae (results not included in Figs. 1 \& 2) had the same abilities to osmoregulate as the zoea IV stage.

A significant change in the pattern of osmoregulation occurred in the megalopa. This stage not only retained hyper-regulation at low salinities but also became slightly hypo-regulating in seawater and in the concentrated medium (1302 $\mathrm{mOsm} \mathrm{kg}^{-1}$ or $44.3 \%$ ). This type of hyper-hypo-regulation was retained in juvenile and adult crabs (Fig. 1), with generally increasing $\mathrm{OC}$ in successive instars (Fig. 2). It is noteworthy, however, that the hyper-OC in the $30 \mathrm{mOsm}$ $\mathrm{kg}^{-1}\left(1.0 \%\right.$ ) medium was already $510 \mathrm{mOsm} \mathrm{kg}^{-1}$ in

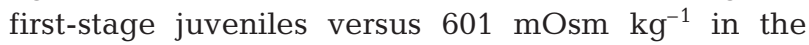
adults. Adult crabs were very strong hyper-hyporegulators. In the range from 300 to $947 \mathrm{mOsm} \mathrm{kg}{ }^{-1}$ (10.2 to $32.2 \%$ ), their hemolymph osmolality was maintained close to constant, with values of 719, 753, 790 and $826 \mathrm{mOsm} \mathrm{kg}^{-1}$, respectively (Fig. 1). In megalopae, juveniles and adults, the transition from hyperto hypo-regulation, i.e. the isosmotic salinity, occurred approximately at 800 to $820 \mathrm{mOsm} \mathrm{kg}^{-1}, 27.2$ to $27.9 \%$.
Table 2. Chasmagnathus granulata. Two-way ANOVA plus a nested factor, for tolerance of zoea 1, as the time elapsed from hatching until mortality reached $50 \%$. The factors were pre(E\%) and posthatching (L\%) salinity, and brood nested in prehatching salinity. dff, MSf, dfe, MSe: degrees of freedom and mean squares of factors and errors, respectively

\begin{tabular}{|lrrrccc|}
\hline Factor & dff & MSf & dfe & MSe & $F$ & p \\
\hline Brood & 9 & 0.17 & 191 & 0.009 & 18.66 & $<10^{-6}$ \\
L\%o & 2 & 3.03 & 9 & 0.168 & 17.98 & $<10^{-3}$ \\
E\% & 3 & 8.12 & 27 & 0.136 & 59.45 & $<10^{-6}$ \\
Brood $\times$ L\%o & 27 & 0.14 & 191 & 0.009 & 15.13 & $<10^{-6}$ \\
E\% $\times$ L\%o & 6 & 3.08 & 27 & 0.136 & 22.57 & $<10^{-6}$ \\
\hline
\end{tabular}

\section{Acclimation effects on salinity tolerance}

Salinity tolerance in the zoea I stage, measured as median time of larval survival $\left(L t_{50}\right)$ at various posthatching salinities $(5,15,25$ or $32 \%$ ), was significantly influenced by previous embryonic acclimation (prehatching salinity: 15, 20 or 32\%; Fig. 3). This effect is reflected in a significant interaction term between pre- and posthatching salinities; in addition, there was statistically significant variability between identically treated broods from different females (Table 2). The highest overall $L t_{50}$ values were found at intermediate posthatching salinities, 15 and $25 \%$, regardless of the conditions of embryonic acclimation.

At the lowest posthatching salinity tested (5\%), the $L t_{50}$ values were generally low, but this acute effect of hypo-osmotic stress was mitigated by low prehatching salinities (Fig. 3). Embryonic acclimation at 15 or $20 \%$ significantly enhanced the capability of freshly hatched zoea I larvae to tolerate $5 \%$. Their average $L t_{50}$ at

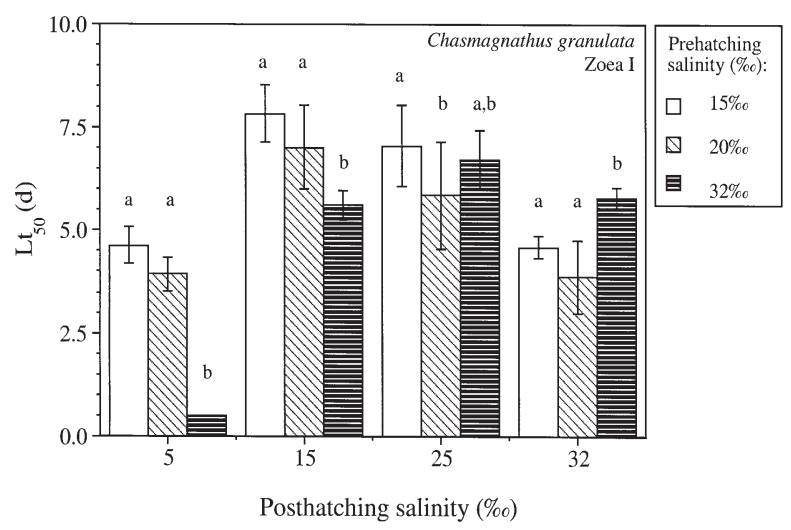

Fig. 3. Chasmagnathus granulata. Mean time elapsed from hatching until mortality reached $50 \%\left(L t_{50}\right)$ of zoea 1 under different pre- and posthatching salinities. Error bars: standard deviation. Different letters indicate significant differences $(p<0.05)$ between posthatching salinities 

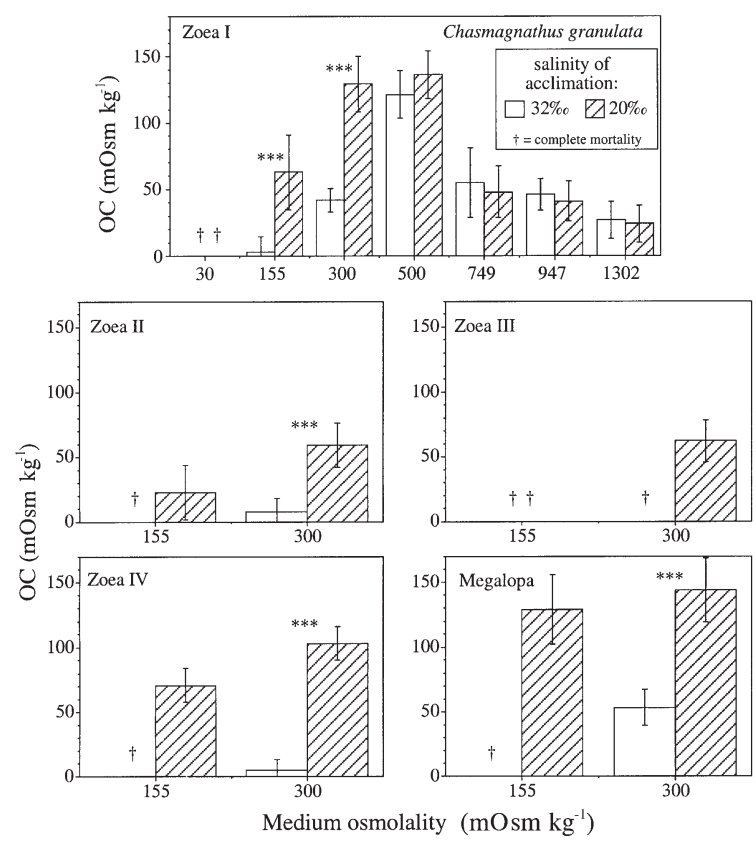

Fig. 4. Chasmagnathus granulata. Variations of the osmoregulatory capacity $(\mathrm{OC})$ in different stages of postembryonic development, whose previous stages had been raised at the salinity 20 or $32 \%$, and exposed for $24 \mathrm{~h}$ at $155 \mathrm{mOsm} \mathrm{kg}{ }^{-1}, 5.3 \%$, and $300 \mathrm{mOsm} \mathrm{kg}{ }^{-1}, 10.2 \%$, at $21^{\circ} \mathrm{C}$; error bars: mean $\pm \mathrm{SD}$; $\mathrm{n}=6$ to 10 individuals; asterisks indicate significant differences

this hypo-osmotic condition was $\geq 4 \mathrm{~d}$, while all zoeae that had hatched after acclimation in seawater (32\%) died within $1 \mathrm{~d}$ after exposure. The same effect of acclimation to brackish water, only weaker, was observed at a moderately reduced posthatching salinity (15\%; Fig. 3). The opposite effect was observed after embryonic development in seawater. In these experiments, the $L t_{50}$ values were maximum at a posthatching salinity of $32 \%$ and significantly lower in dilute media. No clear pattern was found in the experiments with a posthatching salinity of $25 \%$.

\section{Acclimation effects on OC}

The effect of embryonic and larval acclimation at a reduced salinity $(20 \%$ ) on the subsequent larval ability to osmoregulate is illustrated in Fig. 4. Compared with larvae that had previously developed in seawater $(32.2 \%)$, the acclimation in a dilute medium allowed thereafter for generally enhanced survival and higher OC.

Only the zoea I stage was tested at all salinities ranging from 30 to $1302 \mathrm{mOsm} \mathrm{kg}{ }^{-1}$. The lowest salinity (1\%o or 30 mOsm $\mathrm{kg}^{-1}$ ) caused complete mortality within a few hours, regardless of previous acclimation. In zoeae originating from eggs that had previously been incubated at 20\%, $155 \mathrm{mOsm} \mathrm{kg}^{-1}$ (5\%) allowed for higher survival and a significantly enhanced OC (Fig. 4). Enhanced OC values after embryonic acclimation to $20 \%$ were also found in media with 300 and 500 mOsm kg$~^{-1}$ (10.2 and $17.0 \%$ ); in the latter treatment, however, this difference was statistically not significant. At higher salinities, the OC was consistently slightly higher after acclimation in seawater, but again these differences were not significant.

In all later larval stages, tests for acclimation effects on the OC were conducted only at the 2 hyposaline conditions where the response in the zoea I was found to be clearest (155 and $300 \mathrm{mOsm} \mathrm{kg}^{-1}$, or 5 and $10.2 \%$ ). After previous acclimation to seawater, all later zoeal stages (II to IV) and the megalopae died during the 24 to $30 \mathrm{~h}$ experimental exposure to $5 \%$ (155 mOsm kg-1). In contrast, after acclimation to $20 \%$, in these stages (except for the zoea III, where complete mortality occurred in both treatments with differential acclimation), a previous exposure to a dilute medium $(20 \%)$ allowed subsequently for at least some survival at $5 \%$, and the larvae were able to hyper-osmoregulate (Fig. 4).

The same response pattern was also found in the moderately reduced test medium $10.2 \%$ or 300 mOsm $\mathrm{kg}^{-1}$ ). After previous maintenance in seawater, the zoea II and IV larvae were osmoconformers, and all zoea III died at this salinity (Fig. 4). Only the zoea I and the megalopa showed, also after previous exposure to seawater, a significant hyper-OC at $10.2 \%$. After previous acclimation at $20 \%$, the regulatory capacity was 3 to 20 times higher than in larvae originating from seawater.

\section{DISCUSSION}

\section{Patterns of osmoregulation}

Adult Chasmagnathus granulata are strong euryhaline hyper-hypo-osmoregulators, a feature they share with other Grapsidea (Sesarma meinerti: Gross et al. 1966; S. catenata, S. eulimine: Boltt \& Heeg 1975; S. reticulatum: Foskett 1977; S. curacaoense: Anger \& Charmantier 2000; Armases miersii: Charmantier et al. 1998, Schubart \& Diesel 1998) and various Ocypodidae (review in Mantel \& Farmer 1983, Rabalais \& Cameron 1985a). Our results confirm the hyper-hypo-ionoregulatory pattern reported for C. granulata (see MañeGarzon et al. 1974, Luquet et al. 1992, Rebelo et al. 1999, Castilho et al. 2001). The capacity of osmoregulation in C. granulata may be compared with that in A. miersii, one of the most efficient osmoregulators among the decapod crustaceans (Charmantier et al. 1998). In media ranging from approximately 1 to $44 \%$ 
salinity, i.e. for external osmolalities spanning approx-

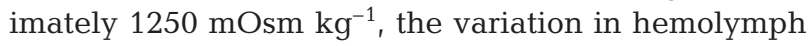
osmolality was only $306 \mathrm{mOsm} \mathrm{kg}^{-1}$ in C. granulata

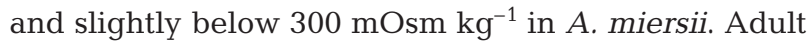
C. granulata are therefore well adapted to habitats where extreme tidal and seasonal fluctuations in salinity occur (D'Incao et al. 1992, Anger et al. 1994, Spivak et al. 1994).

The patterns of osmoregulation in Chasmagnathus granulata change conspicuously during the course of its postembryonic development. In our experiments, the zoeae were hyper-osmoconformers over the entire range of tolerable salinities (stages II to IV) or slight hyper-osmoregulators in dilute media (zoea I). Remarkably, the salinity tolerance was thus wider in the zoea I than in the subsequent zoeal stages. The ability to hyper-regulate, which was present at hatching, reappeared only in the megalopa stage, showing a similar level to that in the zoea I. In the megalopa, the adult pattern of hyper-hypo-osmoregulation was also established, although the capacity to hypo-regulate was still limited. The capacities of both hyper- and hypo-regulation increased markedly following metamorphosis in the first juvenile crab stage, and they continued to increase gradually throughout the subsequent juvenile stages to the adult.

The type of ontogeny of osmoregulation puts Chasmagnathus granulata in the third ontogenetic category (see review in Charmantier 1998), in which the pattern of osmoregulation changes during the postembryonic development. In C. granulata, the principal physiological shift is accomplished at the zoea-megalopa transition, which we consider as the first of 2 metamorphic molts that separate in brachyurans the last zoea from the first crab stage (see Charmantier et al. 1998, for a discussion of metamorphosis in brachyurans). The same timing of transition in the osmoregulatory pattern has been reported from other brachyuran crab species that are strong regulators as adults, for instance in grapsids (Armases miersii: Charmantier et al. 1998; Sesarma curacoense: Anger \& Charmantier 2000) and ocypodids (Uca subcylindrica: Rabalais \& Cameron 1985b). An exception was found in the grapsid Sesarma reticulatum, where the megalopa retains the zoeal pattern of osmoregulation and the physiological transition occurs only at the megalopa-crab I molt (Foskett 1977). Compared with A. miersii, S. curacaoense or $U$. subcylindrica, in which the pattern of ontogeny of osmoregulation is similar, C. granulata presents 2 peculiar features: (1) Although adult C. granulata are strong osmoregulators, the zoeal stages are osmoconformers or weak hyper-osmoconformers; the zoeae of the other 3 species are much stronger hyperregulators in dilute media. For instance, in a $300 \mathrm{mOsm}$ $\mathrm{kg}^{-1}$ medium $(10.2 \%)$, the values of hyper-OC in the zoea I were $210 \pm 9,168 \pm 35$ and $42 \pm 9 \mathrm{mOsm} \mathrm{kg}^{-1}$ in A. miersii (Charmantier et al. 1998), S. curacaoense (Anger \& Charmantier 2000) and C. granulata (present study), respectively. The differences in hyper-OC are yet more conspicuous at a lower salinity $5.3 \%$ or $155 \mathrm{mOsm} \mathrm{kg}^{-1}$ ), e.g. $283 \pm 21 \mathrm{mOsm} \mathrm{kg}^{-1}$ in A. miersii but only $3 \pm 12$ in C. granulata. (2) Among the 3 species compared here, the hyper-OC increases progressively through the successive zoeal stages of $A$. miersii and $S$. curacaoense, whereas it is higher in the zoea I than in all 3 subsequent zoeal stages of $C$. granulata.

More generally, the relations between osmoregulation and salinity tolerance have important ecological implications. In Mar Chiquita lagoon and other estuarine areas populated by Chasmagnathus granulata, the physical conditions are highly variable. Apart from temperature and dissolved oxygen, salinity undergoes both short- and long-term fluctuations, linked to daily tidal water movements and seasons, in the range between approximately 5 and 35\% (D'Incao et al. 1992, Spivak et al. 1994). As one of the dominant crab species whose adults inhabit the lagoon, C. granulata follows an export strategy for the development of the young postembryonic stages. The burrowing adult crabs populate salt marshes, alternately flooded and exposed on each tidal cycle (D'Incao et al. 1992, Spivak et al. 1994). Ovigerous females tend to position their burrows near the channels where the tidal saline inputs flow (D'Incao et al. 1992), thus perhaps minimizing the variations in salinity to which the eggs are exposed. Hatching rhythms seem at least partly synchronized by external factors, including diurnal light and tidal cycles (Anger et al. 1994).

Freshly hatched zoeae I leave their parental environment, usually in less than $1 \mathrm{~d}$ during ebb tides (Anger et al. 1994). Their comparatively higher ability to osmoregulate at low salinity is therefore used during the few hours spent under conditions of variable, on average reduced, salinities. The rest of the zoeal development, during which the osmoconforming zoeae are stenohaline, is spent in adjacent continental shelf waters of the southwestern Atlantic Ocean (Anger et al. 1994), where salinity is supposedly much more stable, around 32 to $34 \%$. Following the export of larvae toward the ocean, the megalopae return into the lagoon for settlement and completion of metamorphosis, most probably with incoming flood tides (Luppi 1999, Luppi et al. 2001). The change in osmoregulatory pattern from the megalopa, which is linked to a rapid and marked increase of euryhalinity, especially in the early juvenile crabs, is one of the main adaptations allowing these young stages to return to conditions of variable salinity. However, the ability to hyper- and hypo-regulate is still low in the megalopa, increasing in subsequent juvenile stages. Megalopae are thus not 
widely tolerant to salinity fluctuations, and their mortality rate may be high following re-import into the lagoon. We thus confirm in this study the hypothesis of Anger et al. (1994, p. 462-463) that 'Osmotic stress... selects for exports mechanisms'. Since in their habitat adults of Chasmagnathus granulata are exposed to low oxygen concentrations to which they respond through air breathing (Lee 1998, Luquet et al. 1998), another advantage of the export strategy might be to expose the water-breathing larvae to open-sea higher oxygen concentrations. In summary, C. granulata zoeae I possess the temporary limited abilities to osmoregulate used to cope with low and variable salinity of the lagoon hatching area, then the exported osmoconforming stenohaline zoeae II to IV develop in marine coastal waters, before the re-import of increasingly osmoregulating and euryhaline megalopae and juvenile crabs into the lagoon.

The ecological implications of the ontogeny of osmoregulation are also exemplified by interspecific comparisons between crab species whose adults are strong hyper-hypo-osmoregulators. In Chasmagnathus granulata, we have seen that the export strategy is associated with the virtual absence of osmoregulatory ability in zoeae, except temporarily in zoea I. In contrast, in species that use a retention strategy, the first posthatch larval stages possess high osmoregulatory capabilities, which result in a wide salinity tolerance. These ecophysiological correlations have been observed in the crabs Uca subcylindrica, Armases miersii and Sesarma curacoense, which breed, respectively, in temporary rainfall puddles (Rabalais \& Cameron 1985b), supratidal rock pools (Anger 1995, Schuh \& Diesel 1995) and coastal mangrove swamps (Atkinson \& Taylor 1988, Macintosh 1988), all habitats where salinity is highly variable. The retention strategy is thus based on a great ability to osmoregulate in all postembryonic stages. In the export strategy, exemplified by $C$. granulata, the larvae are osmoconformers and colonization of a physically harsh environment is accomplished through re-immigration of later stages following the onset of an efficient osmoregulation. In both cases, the early- or late-appearing ability to osmoregulate is most probably based on the development of osmoregulatory organs and tissues.

\section{Physiological plasticity in OC}

Low prehatching salinities (15 and 20\%) resulted in an enhanced resistance to low posthatching salinities (5 and 15\%) during the first zoea of Chasmagnathus granulata (Fig. 1). This pattern must have occurred through an acclimation process and has been found in other crustacean species that occur in estuarine areas, where salinity is highly variable (Rithropanopeus harrisii: Rosenberg \& Costlow 1979, Laughlin \& French 1989; Balanus amphitrite: Qiu \& Qian 1999). Exposure of eggs and larvae of C. granulata to low salinity (20\%) during their development resulted in larvae displaying a higher ability to hyper-regulate in dilute media. These results may be interpreted as evidence of phenotypic plasticity, which is manifested in a change in its $\mathrm{OC}$ in response to the salinity experienced by the previous developmental stage.

Phenotypic plasticity is a term that covers environmentally induced phenotypic variation (Stearns 1989), i.e. morphological or physiological responses of an organism's phenotype to a change in environmental conditions (Schlichting 1989). Previous literature suggests that phenotypic plasticity is an adaptation, as it makes the organism better suited to survive in heterogeneous environments (Scharloo 1989). In Chasmagnathus granulata this plasticity should have an adaptive value, since it should buffer the variability in salinity that characterizes the estuarine environment, enhancing larval survival. This would occur not only in a certain population but also at the populationnetwork-scale, where salinity may vary among estuaries. Egg-carrying females subjected in their habitat to low or variable salinity conditions should thus produce larvae whose OC and salinity tolerance are enhanced. Physiological plasticity as in C. granulata must also be present in other species that are able to acclimate to salinity during their early development (e.g. Rithropanopeus harrisii, Armases miersii, Balanus amphitrite).

Changes in OC may affect all early instars, but they are of particular importance in the 2 stages undergoing a change in habitat, namely the zoea I, which migrates from lagoons to coastal waters, and the re-immigrating megalopa. The first stage does not survive at 5.3\% after an embryonic exposure to $32 \%$, but it is able to weakly hyper-regulate and to survive at this salinity after acclimation at $20 \%$. Also, adult crabs are able to acclimate and to adjust their OC (Cervino et al. 1996), which indicates phenotypic plasticity in Chasmagnathus granulata. If colonization of estuarine and freshwater areas was accomplished through the evolution of larval retention strategies and euryhalinity during the entire larval development, this must have included the acquisition of plasticity in certain anatomical, physiological or molecular features to allow a change in the $\mathrm{OC}$ in response to salinity.

We may expect that salinity experienced by the preceding developmental stages has an influence on the development of osmoregulating tissues and cells, and probably on the activity of the enzymes involved in osmoregulation. Such changes will be a topic for future studies on the ontogeny of osmoregulation in estuarine crustaceans. 
Acknowledgements. We thank Gabriela Torres for helping with mass cultures and experiments on larval survival and Mary-Alice Garcia for her help in typewriting. Financial support to L.G. was given by the Deutscher Akademischer Austauschdienst (DAAD; Bonn, Germany), and the Programa de Desarrollo de Ciencias Básicas (PEDECIBA) in Uruguay.

\section{LITERATURE CITED}

Anger K (1983) Moult cycle and morphogenesis in Hyas araneus larvae (Decapoda, Majidae), reared in the laboratory. Helgol Meeresunters 36:285-302

Anger K (1995) Developmental biology of Armases miersii (Grapsidae), a crab breeding in supratidal rock pools. II. Food limitation in the nursery habitat and larval cannibalism. Mar Ecol Prog Ser 117:83-89

Anger K, Charmantier G (2000) Ontogeny of osmoregulation and salinity tolerance in a mangrove crab, Sesarma curaCaoense (Decapods: grapsidae). J Exp Mar Biol Ecol 251: $265-274$

Anger K, Spivak E, Bas C, Ismael D, Luppi T (1994) Hatching rhythms and dispersion of decapod crustacean larvae in a brackish coastal lagoon in Argentina. Helgol Meeresunters 48:445-466

Atkinson RJH, Taylor AC (1988) Physiological ecology of burrowing decapods. Symp Zool Soc Lond 59:201-226

Bas CC, Spivak ED (2000) Effects of salinity on embryos of two southwestern Atlantic grapsid crab species cultured in vitro. J Crustac Biol 20:647-656

Boltt G, Heeg J (1975) The osmoregulatory ability of three grapsoid crab species in relation to their penetration of an estuarine system. Zool Afr 10:167-182

Bortolus A, Iribarne O (1999) Effects of the SW Atlantic burrowing crab Chasmagnathus granulata on a Spartina salt marsh. Mar Ecol Prog Ser 178:79-88

Boschi EE (1964) Los crustáceos decápodos Branchyura del litoral bonarense (Republica Argentina). Bol Inst Biol Mar Mar del Plata 6:1-76

Boschi EE, Scelzo MA, Goldstein B (1967) Desarollo larval de los especies de Crustáceos Decápodos en el laboratorio Pachycheles haigae Rodrigues Da Costa (Porcellanidae) y Chasmagnathus granulata Dana (Grapsidae). Bol Inst Biol Mar Mar del Plata 6:59-78

Botto F, Iribarne O (1999) Effect of the burrowing crab Chasmagnathus granulata (Dana) on the benthic community of a SW Atlantic coastal lagoon. J Exp Mar Biol Ecol 241: 263-284

Botto F, Iribarne O (2000) Contrasting effects of two burrowing crabs (Chasmagnathus granulata and Uca uruguayensis) on sediment composition and transport in estuarine environments. Estuar Coast Shelf Sci 51:141-151

Castilho PC, Martins IA, Bianchini A (2001) Gill $\mathrm{Na}^{+}, \mathrm{K}^{+}$ATPase and osmoregulation in the estuarine crab, Chasmagnathus granulata Dana, 1851 (Decapoda, Grapsidae). J Exp Mar Biol Ecol 256:215-227

Cervino C, Luquet C, Haut G, Rodríguez E (1996) Salinity preferences of the estuarine crab Chasmagnathus granulata Dana, 1851 after long-term acclimation to different salinities. Atlântica 18:69-75

Charmantier G (1998) Ontogeny of osmoregulation in crustaceans: a review. Invertebr Reprod Dev 33:2-3

Charmantier G, Anger K (1999) Ontogeny of osmoregulation in the palaemonid shrimp Palaemonetes argentinus (Crustacea: Decapoda). Mar Ecol Prog Ser 181:125-129

Charmantier G, Charmantier-Daures M (1994) Ontogeny of osmoregulation and salinity tolerance in the isopod crus- tacean Sphaeroma serratum. Mar Ecol Prog Ser 114: 93-102

Charmantier G, Charmantier-Daures M, Anger K (1998) Ontogeny of osmoregulation in the grapsid crab Armases miersii (Crustacea, Decapoda). Mar Ecol Prog Ser 164: 285-292

Day R, Quinn G (1989) Comparisons of treatments after an analysis of variance in ecology. Ecol Monogr 59:433-436

D'Incao F, Ruffino ML, Silva KG, Braga AC (1992) Responses of Chasmagnathus granulata Dana (Decapoda: Grapsidae) to salt-marsh environmental variations. J Exp Mar Biol Ecol 161:179-188

Drach P (1939) Mue et cycle d'intermue chez les Crustacés Décapodes. Ann Inst Oceanogr Monaco 19:103-391

Drach P, Tchernigovtzeff C (1967) Sur la méthode de détermination des stades d'intermue et son application générale aux Crustacés. Vie Milieu 18A:595-609

Foskett JK (1977) Osmoregulation in the larvae and adults of the grapsid crab Sesarma reticulatum Say. Biol Bull 153: 505-526

Giménez L (2000) El efecto de la salinidad y la biomasa inicial en el desarrollo larval del cangrejo estuarino Chasmagnathus granulata (Crustacea, Decapoda). Doctoral Dissertation, Universidad de la Republica, Uruguay

Giménez L, Anger K (2001) Relationships among egg size, embryonic development, and larval biomass in the estuarine crab Chasmagnathus granulata Dana, 1851. J Exp Mar Biol Ecol 260:241-257

Gross WJ, Lasiewski RD, Dennis J, Rudy P (1966) Salt and water balance in selected crabs of Madagascar. Comp Biochem Physiol 17:641-660

Iribarne O, Bortolus A, Botto A (1997) Between-habitat difference in burrow characteristics and trophic modes in the southwestern Atlantic burrowing crab Chasmagnathus granulata. Mar Ecol Prog Ser 155:137-145

Laughlin R, French W (1989) Interactions between temperature and salinity during brooding on subsequent zoeal development of the mud crab Rhithropanopeus harrisii. Mar Biol 102:377-386

Lee SY (1998) Ecological role of grapsid crabs in mangrove ecosystems: a review. Mar Freshw Res 49:335-343

Luppi TA (1999) La coexistencia de dos especies de cangrejos en el ecosistema del cangrejal: estudio comparativo del asentamiento y el reclutamiento. PhD thesis, Universidad Nacional de Mar del Plata

Luppi TA, Bas CC, Spivak ED, Anger K (1997) Fecundity of two grapsid crab species in the Laguna Mar Chiquita, Argentina. Arch Fish Mar Res 45:149-166

Luppi TA, Spivak ED, Anger K (2001) Experimental studies on predation and cannibalism of the settlers of Chasmagnathus granulata and Cyrtograpsus angulatus (Brachyura: Grapsidae). J Exp Mar Biol Ecol 265:29-48

Luquet CM, Ford P, Rodriguez EM, Ansaldo M, Stella US (1992) Ionic regulation patterns in two species of estuarine crabs. Comun Biol 10:315-325

Luquet CM, Cervino CO, Ansaldo M, Carrera Peryra V, Kocmur S, Dezi RE (1998) Physiological response to emersion in the amyhibious crab Chasmagnathus granulata Dana (Decapoda Grapsidae): biochemical and ventilatory adaptations. Comp Biochem Physiol 121A:385-393

Macintosh DJ (1988) The ecology and physiology of decapods of mangrove swamps. Symp Zool Soc Lond 59:315-341

Mañe-Garzón F, Dei-Cas E, Holeman-Spector B, Lemonie J (1974) Estudios sobre la biología del cangrejo de estuario Chasmagnathus granulata Dana 1851. I. Osmoregulacion frente a cambios de salinidad. Physis A 33:163-171

Mantel LH, Farmer LL (1983) Osmotic and ionic regulation. 
In: Mantel LH (ed) The biology of crustacea, Vol 5. Internal anatomy and physiological regulation. Academic Press, New York, p 53-161

Morritt D, Spicer JI (1995) Changes in the pattern of osmoregulation in the brackish water Amphipod Gammarus duebeni Lilljeborg (Crustacea) during embryonic development. J Exp Zool 273:271-281

Morritt DN, Spicer JI (1996) Developmental ecophysiology of the beachflea Orchestia gammarellus (Pallas) (Crustacea: Amphipoda). I. Female control of the embyronic environment. J Exp Mar Biol Ecol 207:191-203

Morritt D, Spicer JI (1998) The physiological ecology of talitrid amphipods: an update. Can J Zool 76:1965-1982

Morritt D, Spicer JI (1999) Developmental ecophysiology of the beachflea Orchestia gammarellus (Pallas) (Crustacea: Amphipoda: Talitridae). III. Physiological competency as a possible explanation for timing of hatchling release. J Exp Mar Biol Ecol 232:275-283

Nery LEM, Santos EA (1993) Carbohydrate metabolism during osmoregulation in Chasmagnathus granulata Dana, 1851 (Crustacea, Decapoda). Comp Biochem Physiol 106B: $747-753$

Pestana D, Orstrensky A (1995) Occurrence of an alternative pathway in the larval development of the crab Chasmagnathus granulata Dana, 1851 under laboratory conditions. Hydrobiol 306:33-40

Qiu J, Qian P (1999) Tolerance of the barnacle Balanus amphitrite amphitrite to salinity and temperature stress: effects of previous experience. Mar Ecol Prog Ser 188: 123-132

Rabalais NN, Cameron JN (1985a) Physiological and morphological adaptations of adult Uca subcylindrica to semi-arid environments. Biol Bull 168:135-146

Rabalais NN, Cameron JN (1985b) The effects of factors important in semi-arid environments on the early development of Uca subcylindrica. Biol Bull 168:147-160

Rebelo MF, Santos EA, Montserrat JM (1999) Ammonia exposure of Chasmagnathus granulata (Crustacea, Decapoda)

Editorial responsibility: Otto Kinne (Editor), Oldendorf/Luhe, Germany
Dana 1851: accumulation in haemolymph and effects on osmoregulation. Comp Biochem Physiol 122A:429-435

Rosenberg R, Costlow JD (1979) Delayed response to irreversible non-genetic adaptation to salinity in early development of the brachyuran crab Rhithropanopeus harrisii, and some notes on adaptation to temperature. Ophelia 18: 97-112

Scharloo W (1989) Developmental and physiological aspects of reaction norms: Drosophila data link genetic variation and phenotypic response to the environment. BioScience 39:465-471

Schlichting CD (1989) Phenotypic integration and environmental change: what are the consequences of differential phenotypic plasticity of traits? BioScience 39:460-464

Schubart CD, Diesel R (1998) Osmoregulatory capacities and penetration into terrestrial habitats: a comparative study of Jamaican crabs of the genus Armases Abele, 1992 (Brachyra: Grapsidae: Sesarminae). Bull Mar Sci 63: 743-752

Schuh M, Diesel R (1995) Effects of salinity and starvation on the larval development of Sesarma curacaoense De Man, 1892, a mangrove crabs with abbreviated development (Decapoda: Grapsidae). J Crustac Biol 15:645-654

Sokal RR, Rohlf FJ (1995) Biometry. The principles and practice of statistics in biological research. WH Freeman and Co, San Francisco

Spivak E, Anger K, Luppi T, Bas C, Ismael D (1994) Distribution and habitat preferences of two grapsid crabs species in Mar Chiquita Lagoon (Province of Buenos Aires, Argentina). Helgol Meeresunters 48:59-78

Stearns SC (1989) The evolutionary significance of phenotypic plasticity. BioScience 39:436-445

Strathmann RR (1982) Selection for retention or export of larvae in estuaries. In: Kennedy VS (ed) Estuarine comparisons. Academic Press, New York, p 521-535

Susanto GN, Charmantier G (2000) Ontogeny of osmoregulation in the crayfish Astacus leptodactylus. Physiol Biochem Zool 73:169-176

Submitted: May 28, 2001; Accepted: September 6, 2001 Proofs received from author(s): February 12, 2002 